\title{
Stress Analysis of Injection - moulded Cylindrical Parts Reinforced with Short Fibres
}

Oldrich Suba, Libuse Sykorova, Imrich Lukovics

Faculty of Technology , T. Bata University in Zlín, Nám. TGM 275, 76262 Zlín, Czech Republic. suba@ft.utb.cz

An investigation was carried out through a study of the influence of material anisotropy and geometrical parameters of the cylindrical plastic parts reinforced by short fibres, on the state of stress. It has been shown that the result of such injection-moulded processes is an anisotropic product, whose mechanical behaviour differs considerably for that of classical types of isotropic solids. Unlike unreinforced plastics, fibre composites exhibit different stress phenomena and mechanical properties notably in cases where composite parts are highly curved. These unusual effects of their mechanical properties thus need to be considered carefully in the course of designing of reinforced plastic parts.

Keywords: injection moulding, cylindrical bosses, short fibres, stress modelling

\section{References}

[1] BRIGHT, P. F.: J. Mat. Sci., 13., p. 2497,1978

[2] MATSUOKA, T., TAKABATAKE, J.-I., INOUE, Y. and TAKAHASHI, H. Prediction of Fiber Orientation in Injection Molded Parts of Short-Fiber-Reinforced Thermoplastics. Polym. Eng. Sci., 1990, vol. 30, p. 957-966

[3] GUPTA, K. and WANG,K.K. Fiber orientation and mechanical properties of short-fiber-reinforced injectionmolded composites. Polym. Compos., 1993, vol. 14, p. 367-382.

[4] CHUNG, S. T. and KWON, T.H. Numerical simulation of fiber orientation in injection molding of short-fiberreinforced thermoplastics.. Polym. Eng. Sci., 1995, vol. 35, p. 604-618.

[5] SUBA,O. : On Influence of Anisotropy of Thermomechanical Behaviour of Injection moulded Parts Reinforced with Short Fibres. In: Proc. of PPS-16 The Polymer Pocessing Society, Shanghai, China. p. 299-300, 2000

[6] ŠUBA, O., ŽALUDEK, M.: On influence of injection moulding process on mechanical properties of short-fiber filled product.In: Proc. of the Transfer 1999, Brno, Czech Rep., 1999

[7] LEKHNITSKI, S.G.: Anisotropic plates.- Gordon \& Breach Sci.P., N. York, 1968

[8] BÍLEK, O.; LUKOVICS, I. Finite Element Model of Dynamics within Highspeed Grinding Process. Academic Journal of Manufacturing Engineering, 2009, 2 (7), 6-11. ISSN 1583-7904.

[9] BÍLEK, O.; LUKOVICS, I. Surface Grinding and Dynamic Machinability of Polymer Materials. Strojirenská technologie, 2010 , roč. 14, č. zvláštní, s. 20-24. ISSN: 1211-4162.

[10] BÍLEK, O.; LUKOVICS, I. a DANIEL, O. Stiffness Analysis of Machine Frame Using CAD/CAE. In XXIV. microCAD International Scientific Conference Miskolc: University of Miskolc ,2010. s. 21-24. ISBN/ISSN: 978-963-661-918-3.

[11] MADL, J., SUTANTO, H. Hard Machining and Residual Stresses. Manufacturing Technology. 2007, Vol. VII., pp. 5-10, ISSN 1213248-9.

[12] BÍLEK, O., LUKOVICS, I. Determination of the Residual Stress Through the Thickness of Plastic and Metalic Parts. Manufacturing Technology. 2006, Vol. VI., pp. 12-16, ISSN 1213248-9. 